\title{
Biblical Ethics and Application
}

Purview, Validity, and Relevance of Biblical Texts in Ethical Discourse. Kontexte und Normen neutestamentlicher Ethik/Contexts and Norms of New Testament Ethics. Band IX Ed. by Ruben Zimmermann and Stephan Joubert

[Biblische Ethik und deren Anwendung. Geltungsbereich, Gültigkeit und Relevanz biblischer Texte in ethischen Diskursen.]

Biblical Ethics and Application

Edited by RUBEN ZIMMERMANN and STEPHAN JOUBERT

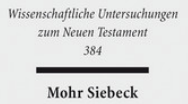

2017. XIII, 431 Seiten. WUNT I 384

ISBN 978-3-16-155718-7

DOI 10.1628/978-3-16-155718-7

eBook PDF 194,00€

ISBN 978-3-16-154823-9

Leinen $194,00 €$
Veröffentlicht auf Englisch.

Die Autoren dieses Sammelbandes diskutieren die Relevanz und den Einfluss zahlreicher alt- und neutestamentlicher Dokumente sowie früher christlicher und jüdischer Texte auf die Bildung moralischer Eigenschaften, Identität und Verhalten der jeweiligen Gemeinschaften, in denen sie entstanden, sowie deren ethische Anwendung über die Jahrhunderte. Entgegen eines begrenzten Verständnisses von Ethik wird der Begriff »Anwendung« nicht verwendet, um die Bibeltexte als Schritt-fürSchritt-Anleitungen für einen angemessenen Lebenswandel zu analysieren. Stattdessen befassen sich die Beiträger mit biblischen Texten innerhalb der Struktur eines komplexen hermeneutischen Prozesses der Anwendung der Relevanz dieser Texte im aktuellen ethischen Diskurs.

\section{Inhaltsübersicht}

Stephan Joubert/Ruben Zimmermann: Biblical Ethics and Application: Introduction - Ellen van Wolde: God's Covenant with the Living Beings on Earth: An Eco-ethical Reading of Genesis 9:8-17 - Bert Jan Lietaert Peerbolte: Protection against Evil: Jesus Christ as Shield and Buckler (Psalm 91) - Ben Witherington, III: The Ethic of Jesus Revisited: An Essay in Honor of Jan van der Watt - Jan Willem van Henten: Negative Peace Re-Assessed: The Case of Herod the Great - Tobias Nicklas: "Let the Dead Bury their Own Dead« (Matt 8:22 par. Luke 9:60): A Commandment without Impact for Christian Ethos? - Joseph Verheyden: Disqualifying the Opponent: The Catalogue of Vices in Matt 15:19 as Characterisation and Criticism - Cilliers Breytenbach: Das Wissen und Nicht-Wissen um die Zeit als Verhaltensregel: Eine textpragmatische Analyse der Endzeitrede in Markus 13 Robert L. Brawley: Jesus as the Middle Term for Relationships with God in the Fourth Gospel - R. Alan Culpepper: The Ethics of the Shepherd - Mirjam Zimmermann/Ruben Zimmermann: Freundschaftsethik im Johannesevangelium: Zur öffentlichen und politischen Reichweite eines ethischen Konzepts - Ulrich Busse: Die johanneische Abschiedsrede, die soziale Lage der Leserschaft und ethische Implikationen - Udo Schnelle: Ethik und Kosmologie bei Paulus - Michael Wolter: "Gebt allen, was ihr schuldig seid ...« (Röm 13,6-7): Was die Verpflichtung von Christen, sich den über sie herrschenden »Obrigkeiten« unterzuordnen, begrenzt - Bart J. Koet: Ethics or Halacha? „Calling« as a key to the dynamics of behaviour according to Paul in 1 Cor 1:1-11 243 - Rainer Hirsch-Luipold: »Ich bete, dass ihr ...«: Impliziter und grammatischer Imperativ im Philipperbrief vor

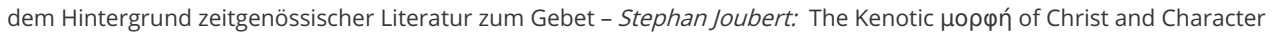
Formation in Paul's Ethical Discourse in Philippians 2:5-11 - D. Francois Tolmie: John Chrysostom and the »Implicit Ethics« of the Letter to Philemon - Michael Theobald: »Lauter Milde allen Menschen gegenüber!« (Tit 3,2): Grenzüberschreitendes Ethos in den Pastoralbriefen - Paul N. Anderson: Identity and Congruence : The Ethics of Integrity in the Johannine Epistles - Craig R. Koester: Babylon and New Jerusalem in the Book of Revelation: Imagery and Ethical Discernment - Michael Labahn: Der Konflikt zwischen Gut und Böse und seine ethische Dimension für frühchristliche Gemeinden in der römischen Provinz Kleinasien: Überlegungen zur Begründungsstrategie der Ethik in der Johannesoffenbarung

Ruben Zimmermann Born 1968; 1999 Dr. theol. from the University of Heidelberg; 2003 Habilitation from the LudwigMaximilians-University München; currently Professor of New Testament and Ethics at the Johannes Gutenberg-University in Mainz, Germany and research associate at the Department of Old and New Testament Studies of the University of the Free State, Bloemfontein, South Africa.

https://orcid.org/0000-0002-1620-4396

Stephan Joubert Born 1958; 1986-90 Minister in the Dutch Reformed Church; 1990-97 Assistant Professor in Biblical Studies, University of Pretoria; 1997-2002 Professor in New Testament Studies, University of Pretoria; 2005-09 Extraordinary Professor in New Testament Studies, University of Pretoria; since 2011 Research Fellow, Radboud University, The Netherland; since 2013 Extraordinary Professor, Contemporary Ecclesiology, University of the Free State, South Africa.

Jetzt bestellen:

https://mohrsiebeck.com/buch/biblical-ethics-and-application-9783161557187?no_cache=1

order@mohrsiebeck.com

Telefon: +49 (0)7071-923-17

Telefax: +49 (0)7071-51104 